\title{
Synthesis and characterization of biodiesel obtained from castor oil transesterification
}

\author{
J. M. Encinar ${ }^{1}$, J. F. González ${ }^{2}$, G. Martínez ${ }^{1}$, N. Sánchez ${ }^{1}$ and C. G. González ${ }^{1}$ \\ ${ }^{1}$ Dpto. Ingeniería Química y Química Física \\ Universidad de Extremadura \\ Campus de Badajoz - Avda. Elvas s/n, 06071 Badajoz (Spain) \\ Phone number:+0034 924 289672, Fax number:+0034 924 289385, e-mail: jencinar@unex.es, \\ ${ }^{2}$ Dpto. Física Aplicada, Universidad de Extremadura \\ Campus de Badajoz - Avda. Elvas s/n, 06071 Badajoz (Spain)
}

\begin{abstract}
The objectives of this work were to optimize the variables affecting transesterification process for biodiesel production from castor oil, non edible oil, by acid catalysis (sulphuric and phosphoric acid) and basic catalysis (potassium methoxide and potassium hydroxide); and to characterize the biodiesel for its use as fuel in compression ignition motors. The studied operation variables were methanol/oil molar ratio $(3: 1$, $6: 1,9: 1,12: 1)$, temperature $\left(25,35,45,55,65^{\circ} \mathrm{C}\right)$, and catalyst amount $(2,3,4$ wt. $\%$ in acid catalysis, and $0.5,1.0,1.5$ wt. $\%$ in basic catalysis). Evolution of each process was followed by gas chromatography, determining the content of methyl esters at different reaction times. Biodiesel was characterized by a set of parameter according to European Standard, EN 14214. The best conditions for transesterification process were 9:1 methanol/oil molar ratio, $65{ }^{\circ} \mathrm{C}$, and the use of potassium methoxide as catalyst with concentration 1.0 wt.\%. In these conditions, obtained biodiesel presents satisfactory values of water content, iodine and saponification values, flash and combustion points, and temperature of $50 \%$ of distillate. However, values of density, kinematic viscosity, cetane index and cold filter plugging point, that are heavily dependent on oil, move away from those required by the European Standard.
\end{abstract}

\section{Key words}

Biodiesel, castor oil, non edible oil, potassium methoxide, transesterification.

\section{Introduction}

Biodiesel is defined by the European Parliament in Directive 2003/30/EC [1] as a "methyl-ester produced from vegetable or animal oil, of diesel quality, to be used as biofuel". Biodiesel is characterized by its biodegradability, nontoxic, renewability, ease of production and agricultural origin $[2,3] . \mathrm{CO}_{2}$ emissions of biodiesel combustion can be considered as recyclable by the growing plants, emissions of $\mathrm{SO}_{\mathrm{x}}, \mathrm{CO}$, unburnt hydrocarbons, and particulate matter are lower than those of petroleum diesel $[4,5]$.

Transesterification of vegetable oils and animal fats is the main way to make biodiesel. Transesterification is a three-step reversible reaction of vegetable oils or animal fats with a short-chain alcohol to form fatty acid methyl esters (FAMEs) and glycerol. The presence of a catalyst is needed. Among the alcohols that can be used in the transesterification process are methanol, ethanol, propanol, butanol and amyl alcohol. Methanol is used most frequently because of its low cost and its physical and chemical advantages (polar and shortest chain alcohol). The stoichiometric ratio for transesterification requires three moles of alcohol, however the molar ratio is associated with the type of catalyst used and higher molar ratios result in greater ester conversion in a shorter time [2]. As catalyst can be used basic and acid substances. Basic catalysts lead to higher conversion of methyl esters at low temperature, atmospheric pressure and minimum response time, which reduces the cost of the process considerably. These catalysts are alkaline hydroxides and methoxides, the hydroxides be preferred because they are cheaper [6]. The drawback of these catalysts is that their use is limited compared to raw materials with high content of free fatty acids, they react with the catalyst through the saponification reaction forming soaps. To avoid this fact acid catalysts are useful because prevent the formation of stable emulsions and generate less waste water during the process of removing them [7]. However, unlike the basic catalysts, require greater reaction times, higher values of molar ratio methanol:oil, catalyst concentration and temperature. The most common are sulfuric acid, phosphoric acid and hydrochloric acid [6, 8].

Castor oil, Ricinus communis L., is a member of the tropical spurge family, Euphorbiaceae, and can nowadays be found naturalized and cultivated in all temperate countries of the world. Castor is amongst the plants with the highest oil yield potential because of its high yield of 
seeds and the high oil content of its seeds. It may be possible to obtain a maximum of $2000 \mathrm{~kg}_{\text {oil }} \cdot \mathrm{ha}^{-1}$ [9]. Whereas rapeseed produces about $1000 \mathrm{~kg}_{\text {oil }} \cdot \mathrm{ha}^{-1}$ and soybean only produces about $500 \mathrm{~kg}_{\text {oil }} \cdot \mathrm{ha}^{-1}$ [10]. Therefore, castor oil is a promising source to produce biodiesel, decreasing the cultivated land.

About chemical and physical characteristics, castor oil composition is 80-90\% ricinoleic acid, 3-6\% linoleic acid, 2-4 \% oleic acid and 1-5\% saturated fatty acids [9]. Ricinoleic acid is the main fatty acid from castor oil, this fatty acid possesses 18 carbons with three highly reactive functional groups: the carbonyl group in $1^{\text {st }}$ carbon, the double linking or insaturation in $9^{\text {th }}$ carbon and the hydroxyl group in $12^{\text {th }}$ carbon. This feature causes castor oil properties are different from other vegetable oils [11]. The high content of ricinoleic acid, with a hydroxyl group, is the reason for castor oil has especially high viscosity and density. Castor oil is also characterized by its high stability, high hygroscopicity and its solubility in alcohol, which affects the transesterification reaction $[9,12,13]$.

Several authors have suggested that methanolysis occurs only in the methanol phase. Low oil concentration in methanol slows down the reaction, and a slow dissolving rate of the oil in methanol causes an ignition period. During its early stages, the transesterification reaction is limited by the low solubility of oil in alcohol, especially in methanol [14]. Castor oil is soluble in methanol, hence, this oil favors the transesterification reaction.

Biodiesel production from castor oil has been studied by several researchers. Response surface methodology was used to optimize the transesterification reaction in traditional conditions. The results showed that reaction temperature affected the reaction slightly, however catalyst amount affected especially $[15,16]$. The reaction using cosolvent was also studied as well as a kinetic study has been carried out [17, 18].

Apart from these researches the properties of castor biodiesel for use in the engine have been evaluated [19].

The aims of this research are the synthesis and the characterization of biodiesel obtained by methanolysis of castor oil.

\section{Materials and Methods}

\section{A. Transesterification Reaction}

The castor seeds were provided by Research Center "La Orden", section of Non Edible Food (Badajoz, Spain). The castor oil was obtained in our laboratory in a mechanical press and then refined. Table I presents castor oil properties. Methanol (99.6\%), potassium methoxide, potassium hydroxide, and sulphuric and phosphoric acids were purchased from Panreac. Methyl esters of ricinoleic, palmitic, stearic, oleic, linoleic, linolenic and erucic acids, employed as standards in the chromatographic determination, were supplied by Sigma-Aldrich.

Transesterification reaction was carried out in a $1000 \mathrm{~mL}$ spherical reactor, provided with thermostat, mechanical stirring, sampling outlet, and condensation systems. This installation was consistent with that utilized in previous works [20, 21] and it showed in Figure 1. The procedure followed is described next. The reactor was preheated to $65^{\circ} \mathrm{C}$ to eliminate moisture, and then $500 \mathrm{~g}$ of castor oil was added. When the reactor reached its established temperature, the methanol and the catalyst were added, amounts calculated for each experiment, and the stirring system was connected, taking this moment as time zero of the reaction. At evenly spaced intervals, $1.5 \mathrm{~cm}^{3}$ of sample withdraw for later chromatographic analysis. Each experiment was prolonged for $3 \mathrm{~h}$, and thus the conversion to esters was practically complete.

Table I.- Castor oil properties

\begin{tabular}{cc}
\hline Density at $15{ }^{\circ} \mathrm{C}$ & $961.20 \mathrm{~kg} \cdot \mathrm{m}^{-3}$ \\
Viscosity at $40{ }^{\circ} \mathrm{C}$ & $258.01 \mathrm{cSt}$ \\
Water content & $0.20 \%$ \\
Saponification value & $180.33 \mathrm{mg}_{\mathrm{KOH}} \cdot \mathrm{g}_{\text {sample }}{ }^{-1}$ \\
Iodine Value & $84.19 \mathrm{gI}_{2} \cdot \mathrm{g}_{\text {sample }}{ }^{-1}$ \\
Acid Value & $1.09 \mathrm{mg}_{\mathrm{KOH}} \cdot \mathrm{g}_{\text {sample }}{ }^{-1}$ \\
Acid Number & 0.55 \\
Molecular Weight & $918.12 \mathrm{~g} \cdot \mathrm{mol}^{-1}$ \\
\hline
\end{tabular}

After cooling, the two phases formatted (upper phase consisted of methyl esters, and the lower phase contained the glycerol, the excess methanol and the remaining catalyst) were separated by sedimentation. The methyl esters were purified by distilling the residual methanol at $80^{\circ} \mathrm{C}$, the remaining catalyst was extracted by successive rinses with distilled water, and, finally, the present water was eliminated by heating at $110^{\circ} \mathrm{C}$.

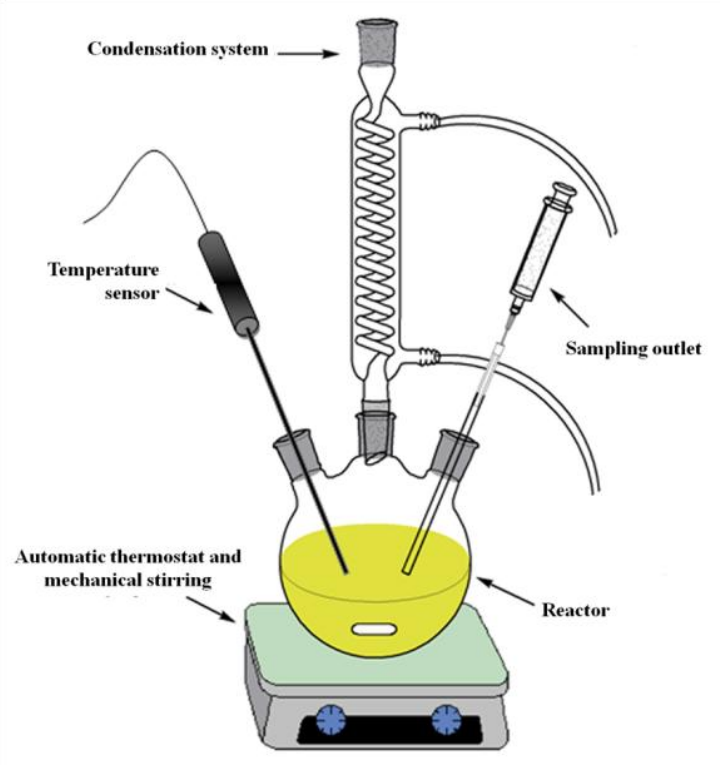

Fig. 1. Experimental transesterification system.

\section{B. Product analysis}

The analytical methods used to determine the characteristics of biodiesel were basically those recommended by the European Organization for Normalization (CEN). This organization specifies the criteria that should be satisfied by biodiesel of high quality, or diesel and biodiesel mixtures, for its use in motor vehicles [22].

Methyl ester content was assayed by gas chromatography in a VARIAN 3900 chromatograph, provided with a FID, 
employing a silica capillary column of $30 \mathrm{~m}$ length, 0.32 $\mathrm{mm}$ ID, and $0.25 \mu \mathrm{m}$ film thickness. Heptane was used as solvent, and the carrier gas was helium at a flow rate of 0.7 $\mathrm{mL} / \mathrm{min}$. The injector temperature was kept at $270{ }^{\circ} \mathrm{C}$, and the detector temperature, $300{ }^{\circ} \mathrm{C}$. Temperature ramp starts with $200^{\circ} \mathrm{C}$, then $20^{\circ} \mathrm{C} / \mathrm{min}$ up to $220^{\circ} \mathrm{C}$.

The following properties of the final biodiesel product were determined: density (pycnometry), kinematic viscosity (Cannon-Fenske routine viscosimeter, size 100), distillation characteristics (ISO 3405 norm), cetane index (UNE 51-119-84), cold filter plugging point, CFPP (EN116), flash and combustion point (EN-116), water content (Karl Fisher), and saponification and iodine values.

\section{Results and Discussion}

The studied operation variables were catalyst types (acid catalysis: sulphuric and phosphoric acids; basic catalysis: potassium hydroxide and potassium methoxide), catalyst concentrations (2, 3 and 4 wt.\% in acid catalysts; 0.5, 1.0 and $1.5 \mathrm{wt} . \%$ in basic catalysts), methanol/oil molar ratio $(3: 1,6: 1,9: 1$ and 12:1) and temperature $(25,35,45,55$ and $\left.65^{\circ} \mathrm{C}\right)$. Reaction time $(3 \mathrm{~h})$ and agitation rate $(700 \mathrm{rpm})$ were fixed as common parameters in all experiments.

\section{A. Types and concentrations of catalyst influence}

Table II shows the results for the catalysts studied. With regard to the two acid catalysts tested, we see that the effectiveness of sulfuric acid was much higher than phosphoric acid, for the same concentration of catalyst. Moreover, as expected, with methoxide use higher performance was achieved than with hydroxide [17, 23]. This is because dissolving the hydroxide to methanol, a small amount of water is formed. This fact is against the transesterification reaction [18].

Table II.- Methyl ester content, as function of catalyst type and concentration catalyst. Reaction conditions: methanol/oil molar ratio, $9: 1$; temperature, $65^{\circ} \mathrm{C}$; time, $3 \mathrm{~h}$.

\begin{tabular}{ccc}
\hline $\begin{array}{c}\text { Type } \\
\text { catalyst }\end{array}$ & $\begin{array}{c}\text { Concentration } \\
\text { catalyst, } \\
\text { wt.\% }\end{array}$ & $\begin{array}{c}\text { Methyl Ester } \\
\text { content, w/w\% }\end{array}$ \\
\hline $\mathrm{H}_{2} \mathrm{SO}_{4}$ & 2 & 74.09 \\
& 3 & 80.34 \\
& 4 & 75.62 \\
\hline $\mathrm{H}_{3} \mathrm{PO} 4$ & 2 & 1.54 \\
& 3 & 2.61 \\
& 4 & 3.68 \\
\hline $\mathrm{KOH}$ & 0.5 & 90.04 \\
& 1.0 & 91.01 \\
& 1.5 & 87.16 \\
\hline $\mathrm{CH}_{3} \mathrm{OK}$ & 0.5 & 94.38 \\
& 1.0 & $\mathbf{9 4 . 6 6}$ \\
& 1.5 & 90.26 \\
\hline
\end{tabular}

Finally, we found that the transesterification reaction of castor oil under study was more favorable with basic catalyst. This oil has low content of free fatty acids and therefore the use of acid catalysts did not result in any improvement to the process.

In general, as the catalyst concentration increased, the conversion of triglycerides also increased. This is because an insufficient amount of catalyst results in an incomplete conversion of triglycerides into fatty acid esters [24]. In basic catalyst, a slight decrease in ester content was observed in the experiments with $1.5 \mathrm{wt} . \%$ of catalyst, with regard to the experiments with $1 \mathrm{wt} \%$. This is because the addition of excess alkaline catalysts caused more triglycerides participation in the saponification reaction, resulting in increased production of soap and mentioned reduction of the esters yield [25].
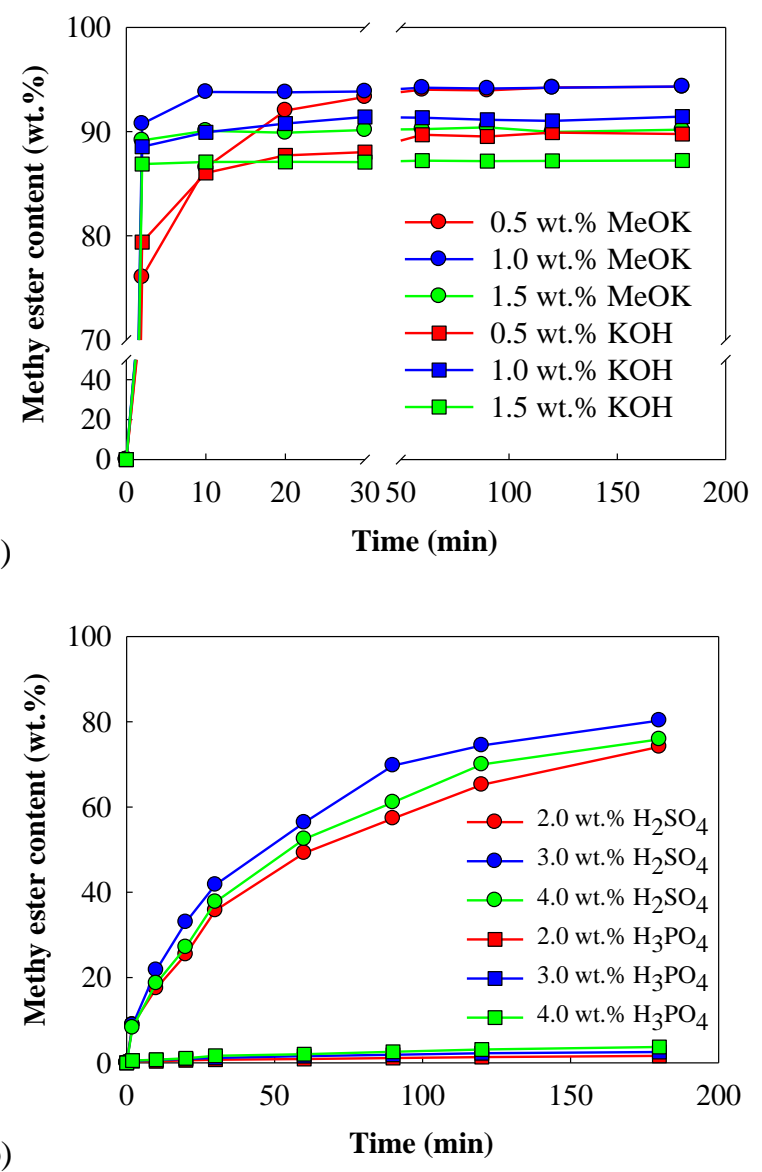

Fig. 2. Methyl ester content, as function of catalyst amount for basic catalysts (a) and acid catalysts (b). Reaction conditions: methanol/oil molar ratio, 9:1; temperature, $65^{\circ} \mathrm{C}$.

Figure 2 shows the evolution of the esters content over time, depending on used concentrations of each catalyst (Figure $2 \mathrm{a}$ for acid catalysis and Figure $2 \mathrm{~b}$ for basic catalysis). With sulfuric acid, the evolution was slow for all concentrations, typical of acid catalysts. In the initial stages, the increase was somewhat faster but became slower when approaching the equilibrium conditions. It is not possible to ensure that steady state was reached after three hours of reaction, although the slopes of the curves indicate that this state should be close. For phosphoric acid can not see anything except an increasing trend over time, given that the conversion was negligible. In basic catalysis, both catalysts gave rise to high concentrations of esters in small reaction times. The difference between the experiments lies in the rate to reach steady state. The rate was higher when the catalyst concentration was increased. In any case, the differences between these experiments were not significant because only in the experiment with 0.5 wt.\% of catalyst, there was a growing area before reaching the asymptote. These trends 
confirm that the reaction rate is enhanced with basic catalysis compared to the acid, such as in the production of biodiesel from other oils [26, 27].

\section{B. Methanol/oil molar ratio influence}

As mentioned, the transesterification activity also depends on the molar concentrations of methanol to oil. Large excess of methanol is required to shift the equilibrium favorably during transesterification for better yields of biodiesel [28]. Methanol/oil molar ratio is associated with the type of catalyst used. In general, acid catalysis requires a methanol/oil molar ratio higher than basic catalysis [2]. To evaluate methanol/oil molar ratio influence the most effective catalysts for acidic and basic catalysis have been chosen. Table III shows experimental conditions and obtained results. In acid catalysis, when methanol/oil molar ratio was increased from 3:1 to 9:1, methyl esters content increased, while from 9:1 to 12:1 there were not significant changes. In basic catalyst similar situation was achieved, except that a slight decrease of methyl esters content was produced by increasing methanol/oil molar ratio from 9:1 to $12: 1$. The higher alcohol molar ratio interferes with the separation of glycerol because there is an increase in solubility. In addition, an excess of alcohol seems to favor conversion of di- to monoglycerides, but there also is a slight recombination of esters and glycerol to monoglycerides because their concentration keeps increasing during the course of the reaction, in contrast to reactions conducted with low molar ratios [20]. In basic catalysis, this effect can be observed because the reaction is fast, whereas in acid catalysis the effect is not apparent, probably due to the low rate of the reaction.

Table III.- Methanol/oil molar ratio influence. Reactor conditions: temperature, $65^{\circ} \mathrm{C}$; time, $3 \mathrm{~h}$.

\begin{tabular}{ccc}
\hline $\begin{array}{c}\text { Methanol/oil ratio, } \\
\text { mol:mol }\end{array}$ & Catalyst & $\begin{array}{c}\text { Methyl Ester } \\
\text { content, w/w\% }\end{array}$ \\
\hline $3: 1$ & $\mathrm{H}_{2} \mathrm{SO}_{4}$, & 64.70 \\
$6: 1$ & 3 wt.\% & 69.55 \\
$9: 1$ & & 80.34 \\
$12: 1$ & & 80.78 \\
\hline $3: 1$ & $\mathrm{CH}_{3} \mathrm{OK}$, & 74.29 \\
$6: 1$ & 1 wt.\% & 80.48 \\
$9: 1$ & & $\mathbf{9 4 . 6 6}$ \\
$12: 1$ & & 91.60 \\
\hline
\end{tabular}

\section{Temperature influence}

The transesterification of castor oil with methanol was carried out at $25,35,45,55$ and $65^{\circ} \mathrm{C}$, in order to determine the temperature influence on the methyl esters production.

Figure 3 shows how the methyl ester yield was almost constant with all studied temperatures after $30 \mathrm{~min}$ of reaction. When the temperature decreased, the reaction rate decreased, but it did so very slight, just noticeable in the first minutes of reaction. From $55^{\circ} \mathrm{C}$, the influence of temperature on reaction rate was not noticeable, reaching the maximum methyl esters content from the first minutes of reaction.

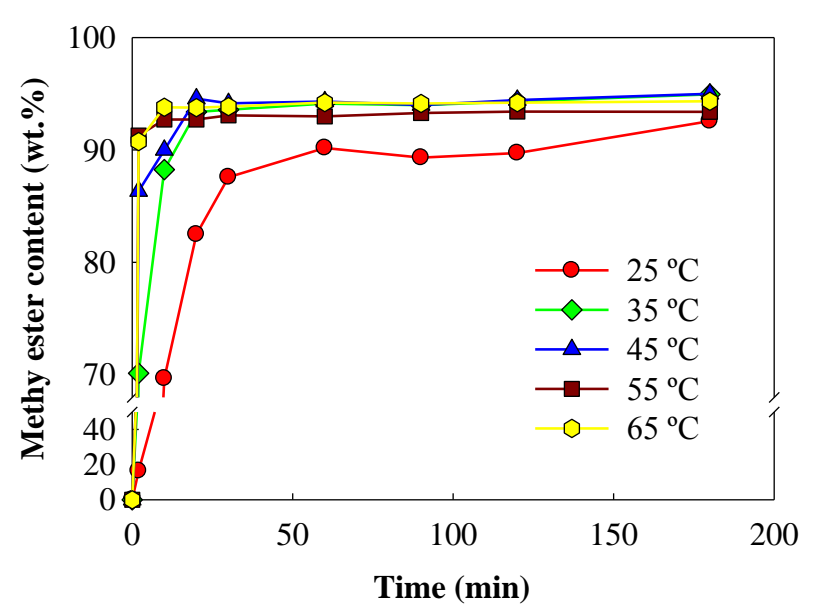

Fig. 3. Influence of the reaction temperature on the methyl ester content. Reaction conditions: catalyst, $\mathrm{CH}_{3} \mathrm{OK}$; catalyst amount, 1 wt.\%; methanol/oil molar ratio, 9:1.

\section{Biodiesel properties}

Table IV shows the properties of biodiesel with higher methyl esters content (other properties depend on esters content [29]). This biodiesel was obtained with the following reaction conditions: 1 wt. $\%$ of potassium methoxide as catalyst, a methanol/oil molar ratio 9:1, 65 ${ }^{\circ} \mathrm{C}$ and $700 \mathrm{rpm}$. By way of comparison, castor oil properties and limits set by European Biodiesel Standards EN 14214 [30] are also shown in Table IV.

Density is a key fuel property, which directly affects the engine performance characteristic. It affects the mass of fuel injected into the combustion chamber and thus, the air-fuel ratio. This is because fuel injection pumps meter fuel by volume not by mass and a denser fuel contains a greater mass in the same volume. Thus, the changes in the fuel density will influence engine output power due to a different mass of fuel injected [31]. It is known that biodiesel density mainly depends on its esters content and the remained quantity of alcohol; hence this property is influenced primarily by the choice of vegetable oil [32]. The density of castor oil used in this work is 961.20 $\mathrm{kg} \cdot \mathrm{m}^{-3}$ and density of biodiesel obtained in better operating conditions was $917.16 \mathrm{~kg} \cdot \mathrm{m}^{-3}$. Although the reduction achieved $(4.58 \%)$ is similar to that of biodiesel made from other oils $[32,33]$, this density value is not within the limits of the standard values. It would therefore be necessary to improve this property with mixtures.

Kinematic viscosity is a measure of resistance to flow of a liquid due to internal friction of one part of a fluid moving over another. Its value affects the atomization of a fuel upon injection into the combustion chamber and thereby, ultimately, the formation of engine deposits. The tendency of the fuel to cause such problems is higher when the viscosity is greater. The kinematic viscosity of biodiesel is about an order of magnitude lower than that of the parent oil [3]. As already mentioned, castor oil has a kinematic viscosity higher than usual caused by the 
presence of the hydroxyl group [34]. Castor oil employed has a viscosity of $258.01 \mathrm{cSt}$, and the more favorable viscosity achieved with transesterification process was of $14.85 \mathrm{cSt}$. This represents a viscosity reduction of $94.2 \%$, however, EN 14214 sets the kinematic viscosity limits between 3.5 and $5.0 \mathrm{cSt}$. As with the density, castor biodiesel breach this rule, the viscosity should be corrected by mixing with other methyl esters or mineral diesel.

Table IV.- Biodiesel properties. Reaction conditions: $\mathrm{CH}_{3} \mathrm{OK}$ as catalyst, 1 wt.\%; methanol/oil, 9:1; $65^{\circ} \mathrm{C} ; 3 \mathrm{~h} ; 700 \mathrm{rpm}$

\begin{tabular}{|c|c|c|c|}
\hline \multirow[b]{2}{*}{ Properties } & \multirow[b]{2}{*}{ Biodiesel } & \multicolumn{2}{|c|}{ EN 14214} \\
\hline & & Min. & Max. \\
\hline Methyl Ester content, w/w\% & 94.66 & 96.5 & - \\
\hline Density at $15^{\circ} \mathrm{C}, \mathrm{kg} \mathrm{m}^{-3}$ & 917.16 & 860 & 900 \\
\hline Viscosity at $40^{\circ} \mathrm{C}, \mathrm{cSt}$ & 14.85 & 3.50 & 5.00 \\
\hline Water content, $\mathrm{mg} \mathrm{kg}^{-1}$ & 600 & - & 500 \\
\hline $50 \%$ Distillation, ${ }^{\circ} \mathrm{C}$ & 321 & - & - \\
\hline Cetane index & 36.91 & 51.0 & - \\
\hline Flash point, ${ }^{\circ} \mathrm{C}$ & 205 & 120 & - \\
\hline Combustion point, ${ }^{\circ} \mathrm{C}$ & 215 & - & - \\
\hline Cold filter plugging point, ${ }^{\circ} \mathrm{C}$ & 17 & -20 & 5 \\
\hline Iodine value, $\mathrm{gI}_{2}(100 \mathrm{~g})^{-1}$ & 82.49 & - & - \\
\hline Saponification value, $\mathrm{mg}_{\mathrm{KOH}} \mathrm{g}^{-1}$ & 182.40 & - & - \\
\hline
\end{tabular}

Water in the biodiesel can promote microbial growth, lead to tank corrosion, participate in the formation of emulsions, as well as cause hydrolysis or hydrolytic oxidation [35]. Water content of obtained biodiesel is similar to the established maximum.

Temperature of $50 \%$ of distillated was determined by aim to calculate cetane index. It is a relative measure of the interval between the injection of the fuel into the cylinder and the onset of auto-ignition, i.e. the ignition delay time. The higher cetane number, the shorter the ignition delay time [29]. As with the mentioned properties, the cetane number of obtained biodiesel did not meet the requirements of the standard.

Flash and combustion points are parameters to consider in the handling, storage, and safety of biodiesel. Minimum flash point established is $120^{\circ} \mathrm{C}$, biodiesel obtained in this research has a value higher than the limit.

One of the major problems associated with the use of biodiesel is poor low temperature flow properties [36]. Cold filter plugging point (CFPP) is defined as the highest temperature at which the fuel, when cooled under defined conditions, does not flow through a filter wire mesh within a certain time. This parameter is related to the cold engine start, and should be sufficiently low, as if the biodiesel freezes, the engine will not start [20]. The cold-flow problems are caused by the presence of high amounts of saturated fatty acid esters [37]. Castor oil biodiesel has a high CFPP despite having a lower content of saturated fatty acids. This limitation is mainly caused by its viscosity, which increases as the temperature decreases and, therefore, flows more slowly. The filter does not get clogged, but biodiesel does not flow in the time required for analysis.

Iodine number is a measure of total unsaturation within a mixture of fatty material. Its value only depends on the origin of the vegetable oil, the biodiesel obtained from the same oil should have similar iodine values [20]. In Table
IV it is possible observer that iodine index is within the limits.

Saponification value is related to the average molecular weight of the sample. When de molecular weight decreases, the saponification value increases. Saponification values increased with the yield of methyl ester [20]. European Biodiesel Standard EN 14214 does not specify any saponification value.

\section{Conclusions}

Castor oil may be a suitable raw material for the transesterification. In the best conditions of reaction, esters content was $94.66 \%$, close to $96.5 \%$ required by European Standard EN 14214.

The most suitable catalyst for this process proved to be potassium methoxide. The other basic catalyst, potassium hydroxide, achieved similar results but its methyl esters contents were slightly lower. On the other hand, the acid catalysts studied, sulfuric and phosphoric acid, obtained yields in methyl esters were poor, even with higher catalyst concentrations. In the case of phosphoric acid, its yield was negligible. The optimum concentration of potassium methoxide catalyst was $1 \mathrm{wt} . \%$.

The best molar ratio of methanol was $9: 1$, for both acid and basic catalysis. This variable exerted a positive influence in obtaining methyl esters until this value. Above 9:1, the conversion of methyl esters begins to decrease slightly.

Transesterification reaction was conducted at all temperatures tested $\left(25,35,45,55\right.$ and $\left.65^{\circ} \mathrm{C}\right)$. This variable exerted a positive influence on the reaction rate, although not significant. The final concentration of methyl esters was almost the same for all temperatures.

In these conditions, the biodiesel presented satisfactory values of water content, iodine and saponification values, flash and combustion points, and temperature of $50 \%$ of distillate. However, values of density, kinematic viscosity, cetane index and cold filter plugging point, that are heavily dependent on oil, move away from those required by the European Standard. This biodiesel should be corrected by mixing with other methyl esters or mineral diesel for its use as diesel fuel.

\section{Acknowledgement}

The authors express their gratitude to the "MICINN" and the "Junta de Extremadura" for the financial support received to perform this study by means of Projects ENE2009-13881, PRI09B102 and PDT 09A037 respectively.

\section{References}

[1] Directive 2003/30/EC of the Eurpoean Parliament and of the Council of 8 May 2003 on the promotion of the use of biofuels or other renewable fuels for transport, Official Journal of the European Union, (2003).

[2] F. Ma and M. A. Hanna, "Biodiesel production: a review", in Bioresource Technology, (1999), Vol. 70, pp. 1-15.

[3] G. Knothe, Krahl, J., Van Gerpen, J., "The Biodiesel Handbook", AOCS Champaign IL., (2005). 
[4] C. R. Coronado, J. A. de Carvalho, Jr., J. T. Yoshioka and J. L. Silveira, "Determination of ecological efficiency in internal combustion engines: The use of biodiesel", in Applied Thermal Engineering, (2009), Vol. 29, pp. 1887-1892.

[5] G. Knothe, C. A. Sharp and T. W. Ryan, "Exhaust Emissions of Biodiesel, Petrodiesel, Neat Methyl Esters, and Alkanes in a New Technology Engine", in Energy \& Fuels, (2006), Vol. 20, pp. 403-408.

[6] M. K. Lam, K. T. Lee and A. R. Mohamed, "Homogeneous, heterogeneous and enzymatic catalysis for transesterification of high free fatty acid oil (waste cooking oil) to biodiesel: A review", in Biotechnology Advances, (2010), Vol. 28, pp. 500518.

[7] N. U. Soriano Jr, R. Venditti and D. S. Argyropoulos, "Biodiesel synthesis via homogeneous Lewis acid-catalyzed transesterification", in Fuel, (2009), Vol. 88, pp. 560-565.

[8] K. G. Georgogianni, A. K. Katsoulidis, P. J. Pomonis, G. Manos and M. G. Kontominas, "Transesterification of rapeseed oil for the production of biodiesel using homogeneous and heterogeneous catalysis", in Fuel Processing Technology, (2009), Vol. 90, pp. 1016-1022.

[9] V. Scholz and J. N. da Silva, "Prospects and risks of the use of castor oil as a fuel", in Biomass and Bioenergy, (2008), Vol. 32, pp. 95-100.

[10] M. Balat and H. Balat, "Progress in biodiesel processing", in Applied Energy, (2010), Vol. 87, pp. 1815-1835.

[11] M. M. Conceição, R. A. Candeia, F. C. Silva, A. F. Bezerra, J. V. J. Fernandes and A. G. Souza, "Thermoanalytical characterization of castor oil biodiesel", in Renewable and Sustainable Energy Reviews, (2007), Vol. 11, pp. 964-975.

[12] M. M. Conceiçao, R. A. Candeia, H. J. Dantas, L. E. B. Soledade, V. J. Fernandes Jr and A. G. Souza, "Rheological behavior of castor oil biodiesel", in Energy and Fuels, (2005), Vol. 19, pp. 2185-2188.

[13] D. S. Ogunniyi, "Castor oil: A vital industrial raw material", in Bioresource Technology, (2006), Vol. 97, pp. 1086-1091.

[14] H. Han, W. Cao and J. Zhang, "Preparation of biodiesel from soybean oil using supercritical methanol and $\mathrm{CO} 2$ as cosolvent", in Process Biochemistry, (2005), Vol. 40, pp. 31483151.

[15] N. De Lima Da Silva, C. B. Batistella, R. M. Filho and M. R. W. Maciel, "Biodiesel production from castor oil: Optimization of alkaline ethanolysis", in Energy and Fuels, (2009), Vol. 23, pp. 5636-5642.

[16] G. T. Jeong and D. H. Park, "Optimization of biodiesel production from castor oil using response surface methodology", in Applied Biochemistry and Biotechnology, (2009), Vol. 156, pp. $1-11$.

[17] R. Peña, R. Romero, S. L. Martínez, M. J. Ramos, A. Martínez and R. Natividad, "Transesterification of castor oil: Effect of catalyst and co-solvent", in Industrial and Engineering Chemistry Research, (2009), Vol. 48, pp. 1186-1189.

[18] K. Ramezani, S. Rowshanzamir and M. H. Eikani, "Castor oil transesterification reaction: A kinetic study and optimization of parameters", in Energy, (2010), Vol. 35, pp. 4142-4148.

[19] N. L. Panwar, H. Y. Shrirame and B. R. Bamniya, "CO2 mitigation potential from biodiesel of castor seed oil in Indian context", in Clean Technologies and Environmental Policy, (2009), Vol. pp. 1-4.

[20] J. M. Encinar, J. F. González and A. Rodríguez-Reinares, "Biodiesel from Used Frying Oil. Variables Affecting the Yields and Characteristics of the Biodiesel", in Industrial \& Engineering Chemistry Research, (2005), Vol. 44, pp. 5491-5499.

[21] J. M. Encinar, J. F. González and A. Rodríguez-Reinares, "Ethanolysis of used frying oil. Biodiesel preparation and characterization", in Fuel Processing Technology, (2007), Vol. 88 , pp. 513-522.

[22] P. Heinrich, "High biodiesel quality required by European Standards", in European Journal of Lipid Science and Technology, (2002), Vol. 104, pp. 371-375.
[23] G. Vicente, M. Martínez and J. Aracil, "Integrated biodiesel production: a comparison of different homogeneous catalysts systems", in Bioresource Technology, (2004), Vol. 92, pp. 297-305.

[24] D. Y. C. Leung, X. Wu and M. K. H. Leung, "A review on biodiesel production using catalyzed transesterification", in Applied Energy, (2010), Vol. 87, pp. 1083-1095.

[25] T. Eevera, K. Rajendran and S. Saradha, "Biodiesel production process optimization and characterization to assess the suitability of the product for varied environmental conditions", in Renewable Energy, (2009), Vol. 34, pp. 762765 .

[26] I. C. F. Dos Santos, S. H. V. De Carvalho, J. I. Solleti, W. Ferreira de La Salles, K. Teixeira da Silva de La Salles and S. M. P. Meneghetti, "Studies of Terminalia catappa L. oil: Characterization and biodiesel production", in Bioresource Technology, (2008), Vol. 99, pp. 6545-6549.

[27] A. Da Silva César and M. Otávio Batalha, "Biodiesel production from castor oil in Brazil: A difficult reality", in Energy Policy, (2010), Vol. 38, pp. 4031-4039.

[28] R. Sree, N. Seshu Babu, P. S. Sai Prasad and N. Lingaiah, "Transesterification of edible and non-edible oils over basic solid Mg/Zr catalysts", in Fuel Processing Technology, (2009), Vol. 90, pp. 152-157.

[29] A. A. Refaat, "Correlation between the chemical structure of biodiesel and its physical properties", in International Journal of Environmental Science and Technology, (2009), Vol. 6, pp. 677-694.

[30] European Standard EN 14214. European Committe for Standardization. "Automotive fuels - Fatty acid methy esters (FAME) for diesel engines - Requerimentes and test methods", (2002).

[31] E. Alptekin and M. Canakci, "Determination of the density and the viscosities of biodiesel-diesel fuel blends", in Renewable Energy, (2008), Vol. 33, pp. 2623-2630.

[32] Z. J. Predojevic, "The production of biodiesel from waste frying oils: A comparison of different purification steps", in Fuel, (2008), Vol. 87, pp. 3522-3528.

[33] J. M. Encinar, J. F. González, A. Pardal and G. Martínez, "Rape oil transesterification over heterogeneous catalysts", in Fuel Processing Technology, (2010), Vol. 91, pp. 1530-1536.

[34] G. Knothe and K. R. Steidley, "Kinematic viscosity of biodiesel fuel components and related compounds. Influence of compound structure and comparison to petrodiesel fuel components", in Fuel, (2005), Vol. 84, pp. 1059-1065.

[35] C. B. Prakash, "A critical review of biodiesel as a transportation fuel in Canada", in GCSI - Global Change Strategies International, Canada (1998).

[36] G. Knothe, "Dependence of biodiesel fuel properties on the structure of fatty acid alkyl esters", in Fuel Processing Technology, (2005), Vol. 86, pp. 1059-1070.

[37] G. Knothe, "Biodiesel and renewable diesel: A comparison", in Progress in Energy and Combustion Science, (2010), Vol. 36, pp. 364-373. 